This manuscript was accepted for publication in "Current sociology" after revision https://doi.org/10.1177/0011392118811392

\title{
The sources of academic localism and globalism in Russian sociology: The choice of professional ideologies and occupational niches among social scientists
}

\section{Abstract}

Why do social scientists choose certain theoretical and methodological stances over others? Three broad explanatory models can be derived from literature on the sociology of social sciences: (1) worldview, arguing that intellectual preferences reflect general cultural and political orientations of broad social groupings to which an individual belongs; (2) status, according to which all forms of hierarchies are reproduced in the academic field through preferences for innovative research by those occupying dominant positions and their avoidance by agents lacking resources; (3) ecological, holding that opportunity structures existing at the historical moment at which an individual enters the academic field determines the theory choice. We analyse the adoption of localist or globalist professional ideologies, favouring an international career and global recognition over a domestic one, or vice versa, to explore the biographical antecedents of choosing one side over the other in an important disciplinary divide. In doing so, we rely on statistical data from a community study of sociology in Leningrad-St Petersburg between 1984 and 2011. The worldview hypothesis finds the strongest support; choice preference for national or international scholarship reflects more general liberal or conservative attitudes characteristic of certain milieus existing in Russian society.

\section{Keywords}

Sociology of sociology, sociology of knowledge, intellectual movements, theory choices, indigenous sociology, sociology in Russia

\section{Author/Corresponding author}

Mikhail Sokolov, Sociology department, European university at Saint Petersburg, Gagarinskaya 6/1, 191187, Saint Petersburg, Russia

E-mail: msokolov@eu.spb.ru 


\section{Introduction}

This paper is intended as a contribution to two discussions. The first is the discussion on biographical determinants of theoretical and methodological choices in the social sciences. Our idea of a social scientist's life course holds that possibly the most important episode in it is the choice between several competing intellectual positions or traditions, such as positivism, phenomenology or poststructuralism. ${ }^{1}$ Its importance for the discipline arises from the fact that the aggregation of such choices results in maintaining an intellectual consensus, or producing a shift in dominant approaches or paradigms-a scientific revolution. While the choice of one competing paradigm, theory, professional ideology or workstyle is understood as both a turning point in an individual's intellectual career and the development of scholarship in general, the subject is scarcely researched empirically, and only very few studies have addressed theory adoption in the social sciences. This paper is aimed at partially filling this gap.

The second issue this paper addresses are the causes of choosing a specific professional stance, that is, for doing predominantly local or global social science. For academics in nonEnglish speaking countries today, picking a side means making an uneasy choice between publishing in international English-language periodicals-and addressing their discipline globally-and publishing in their native language in domestic editions and addressing a narrower audience, sometimes confined within the borders of their nation-state. Choosing one or the other entails decisions such as in which country to finish one's PhD, which social networks to cultivate, conferences to visit, and, largely, of literatures to follow, of genre conventions to adopt, theories to rely on, methods to use and themes to study. A few studies demonstrated that segregation between those wholly oriented to an international career and those oriented to a national one indeed exist in various countries, with "cosmopolitans" 
and "locals" affiliated with different institutions and using different publishing circuits (Sokolov, 2009; Hanafi 2011; Biegel, 2014; see also Fourcade, 2006: 174-80). There have so far been, however, few attempts to study the biographic antecedents of such choices, as well as correlates of the systems of attitudes advocating them and favouring one forms of achievement over others. This study is aimed at partially filling this gap.

This paper will first review the literature on the two issues at hand: theory choices and the local/global divide in social sciences, then go on to describe the research field, that of sociology in present-day Russia, and subsequently discuss methods and empirical findings.

\section{Why do social scientists choose the sides they choose?}

When Harriet Zukerman identified the problems of theory and topic choice as central to the whole project of the sociology of science in 1978 , she was only able to cite few studies investigating how such choices are made (Zuckerman, 1978). While significant progress has since been made, it has been limited by, among other things, the drastic discontinuity between a more theoretical literature mostly relying on historical case studies, and more empirical literature on theory adoption using quantitative analysis.

The explanations of theory choices found in theoretical literature could be situated between one of two poles. On the one pole we find, as the major explanatory mechanism, conceptual schemata referring to worldviews characteristic of wide social groupings to which the chooser belongs. This position might be called a worldview model. On the other pole we find an emphasis on incentives specific to the intellectual field (what we will call career model). The worldview model holds that a scholar's theoretical orientation is but a continuation of a more general perspective originating in the class position one occupies (other approaches in this vein point to gender, ethnicity, etc.). This perspective emerges either as a reflection of social experience or as a form of ideology instrumental in legitimizing the dominant order or in challenging it. The worldview theorizing was present in the 1970s sociology of natural- 
scientific or mathematical knowledge, although in this field it was subsequently replaced by newer versions of science and technology studies that abandoned looking for broad correlations between ideas and the class origins of their inventors and adopters. In contrast to the analysis of natural sciences, attempts to find 'class interests' behind theoretical or methodological positions are still widespread as far as the social sciences are concerned. A prototypical example here is Alvin Gouldner's classic book, The Coming Crisis of Sociology, where Gouldner criticizes Talcott Parsons' systems theory as an expression of an establishment conservative orientations (Gouldner, 1970).

In contrast to the worldview model, which accepts a direct correlation between the structural position of thinkers and the contents of their theoretical or methodological views, the career model holds that the adoption of theoretical beliefs, professional ideologies and work styles reflects the career benefits an individual might expect from such choices. The career model exists in two varieties: status and ecological. The status model suggest that class attributes influence the general strategy of building an intellectual career (Bourdieu, $1975,1988)$. Those who are from privileged social backgrounds, male, and are located within elite academic networks are more likely to reach career success as they are more likely to ${ }^{2}$ identify and invest in the development of less conventional lines of work and follow less conventional, but potentially much more rewarding career paths (Bourdieu, 1975). While the character of these careers cannot be specified in advance-they are contingent on what is considered 'conventional' at the moment-such paths are likely to require the widest and most extensive training, including proficiency in mathematics, philosophy, languages or literary skills. This view corroborates the abounding evidence that innovations originate in the dominant centres in all kinds of fields, not only academic. That those enjoying the highest status are most likely to be early adopters of radical intellectual innovations (Frickel \& Gross 2005). 
In contrast to both the worldview model and the status variety of the career model, which both see an individual's social class as a likely correlate of their intellectual allegiances, another type of career model, ecological, claims that it is the changes in structures of opportunity one encounters at the formative period of one's career that are responsible for subsequent intellectual and professional choices (Ben-David and Collins, 1966). Thus, Randall Collins suggests, rather than the privileged social background of individuals, it is the general economic and organizational expansion of a discipline occurring when they enter the labour force that is responsible for their breaking with the intellectual past: when opportunities abound, new movement can easily find resources and joining it is a good career strategy (Collins, 1998). Further, sociology as a discipline depends on support by various external publics. It is the particular configuration of such publics that stands behind the list of occupational niches available to sociologists at a given period-e.g., public intellectual or social engineer. Each niche makes special demands on its occupants, and an individual's beliefs, skills, or styles of work adapt to a particular niche (e.g. see Kropp, 2013 on epistemic divides between applied and academic sociologists in Denmark). Ecological theorizing recognizes the predominant role of historical changes in the available niches in shaping the face of sociology (e.g. Wagner, 2001 on the role of coalitions with progressive government in the sociological positivism). As a result of changing demand, the overpopulation of existing niches and other factors, different generations face different opportunities and are likely to specialize in different niches. For all versions of the ecological model, academic age is the most important individual attribute as it determines availability and attractiveness of different niches at the moment individuals start their academic career. The relations between the three models are depicted in Figure 1. 


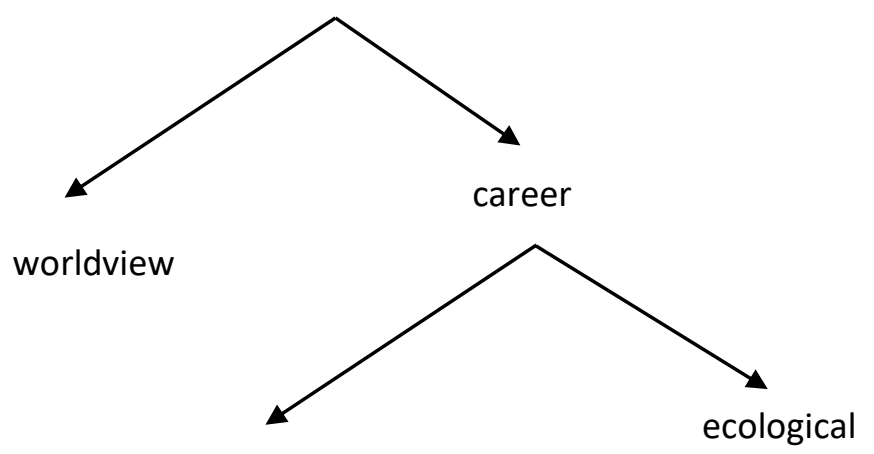

status

\section{Figure 1. The theoretical models}

While all three explanatory models are present in the history of social sciences, there have been only limited attempts to test them directly. In an early example, a pioneering work by Seymour Lipset and Everett Ladd (1972) attempted to test Gouldner's claims that adoption of structural functionalism is an expression of the general conservative political leanings of the adopters (they found that, surprisingly, Parsonians were more likely to be on the political left than the average US sociologist).

With this notable exception, Neil Gross's paper (2002) is possibly the only attempt to compare statistically the explanatory power of various theoretical models in accounting for theory choices in social sciences and humanities. Gross found significant correlation between socio-economic status and variables characterizing an individual's cultural capital on the one hand, and choice of philosophical tradition on the other hand (e.g., knowledge of French or symbolic logic made studying continental or analytical philosophy, correspondingly, more likely), although variables related to identities and general worldviews (Catholicism, strong identification with American history) also proved significant. This theoretical discussion existed in isolation from a bundle of empirical studies of theory adoption, most of which looked for correlations between age and likelihood of embracing intellectual innovations. These studies produced important, although not unambiguous findings (Jones, Reedy and Weinberg, 2014). However, one finds little attempt in these 
studies to discover which one of several candidate mechanism, from age-related changes in intelligence to having greater stakes in the intellectual status quo, could account for whatever age differentials are observed.

\section{Global sociology and its discontents}

In many countries, including most post-Soviet ones, one encounters a divide running across many social-scientific disciplines that opposes those who identify themselves with international and global science with those who are oriented towards predominantly local debates and audiences. The most immediate correlate of this orientation, for non-English speaking countries, is the choice of primary language to write one's results in and circuits in which to publish them. This choice, however, is not limited to the preference of a certain transmission medium, as addressing different audiences implies asking different research questions these audiences would regard as important, using empirical methods they would regard as up-to-date and convincing, and following literatures in the context of which one's findings will be placed by their readers. While most would agree that, ideally, everybody should address all publics, some decisions on allocation of time and other resources between the tasks of reaching different audiences is still inevitable. This allocation is even more evident at an institutional level, at which academic organisations and national research systems in general have to establish the relative weight of credentials and symbols of academic recognition originating from different intellectual scenes (Is a degree from Cambridge more valuable than one from a leading country's university? Should publications in leading national periodicals be given equal weight as those in international ones in promotions decisions?). In this article, we will call beliefs favouring international over national scholarship as "globalist", while the opposite beliefs will be called "localist". 
The precise details of the divide between localist and globalist are probably highly countryspecific and depend on the language spoken by its population, character of the country's cultural and political ties with other countries, and the international reputation of a given discipline within it. Probably the best-known expression of localist beliefs is the intellectual movement calling for the development of what is called indigenous science (Fahim and Helmer, 1980; Jahoda 2016). The ideologists of this movement shun what they call 'academic dependency', 'cultural' or 'academic imperialism', or, as one seminal paper defines it, the 'domination of one people by another in their world of thinking' (Alatas, S. H., 2000: 24). The expression of such domination is located in a well-documented fact that the leading institutional centres, influential publications, and most renowned authors are disproportionally located in the countries identified with "the West" or "the global North" (Heilbron, 2014).

The indigenous science movement deems this situation regretful for two major reasons. First, it argues that theoretical models originating from the global North have limited theoretical relevance for the global South. At the same time, as gatekeepers of the most important professional forums originate from the global North, Southern perspectives have limited possibilities of getting through their filters and reaching their audiences. As a result, the views of non-Western or non-Northern scholars remain largely marginalized even in the countries of the South themselves, lacking the legitimacy of 'international recognition' or 'visibility'.

Second, these externally located sources of disciplinary recognition leads to the suppression of certain research styles and the abandoning of important roles sociologists could play in their societies. 'Applied' or 'public' sociologies, serving local clients for local issues, have to use the same language as its audiences. Moreover, the research questions they pose are likely to be much more relevant to citizens of the same political communities, rather than colleagues abroad. In contrast, purely academic research has less reason to stick to local 
languages, and wider opportunity to reach a truly international audience (Hanafi, 2011). The intellectual dominance of the global North means the suppression of applied research that could immediately contribute to local development in the South, and forced flourishing of detached academism.

The indigenous scholarship movement was pioneered by anthropologists in the 1970s (Fahim and Helmer, 1980), soon enough spreading to psychology, and later, sociology and other social sciences. Possibly the first call for an indigenous sociology was voiced by Frederick Gareau (1988). While widespread, the indigenous sociology movement is still only one form of localism. Its other forms can be found in the countries of the global North themselves, particularly those non-English speaking ones which once enjoyed the status of centres of non-English speaking 'academic empires' (France, Germany, Russia). The Russian case, described in more detail below, belongs to this category.

The opposite position, dubbed here 'globalism', is not represented by an organized movement with an articulate ideology decrying localism, akin to indigenous sociology. Rather, it relies on the legitimizing myths of science as a cumulative and universalistic enterprise, and to institutional pressures arising from the global spread of university rankings that make English-language publications an important asset for any higher education institution globally.

In spite of the broad spread of the indigenous sociology movement and nearly universal presence of some forms of academic localism and globalism, there have been few studies of them, and nearly none have explored whether the choice of work style and professional niche precedes choice of ideology or follows from it (partial exception is Gabrenya et al, 2006).

The three models listed above give conflicting predictions. What we have called the worldview model suggests that one's position at the globalist-localist divide is likely to primarily correlate with more general political and cultural attitudes, the influence of class 
on professional ideology choice will be indirect and mediated by general ideology, and the choice of an occupational niche or work-style will largely follow from both general ideological attitudes and the professional ideology one embraces.

From the point of view of both status and ecological varieties of the career model, professional ideologies are accepted as a rationalization of choices of occupational niches made for economic reasons. For example, those who turn to international academia for better economic prospects and societal prestige will develop scorn towards what they see as provincialism; those seeing more prospects at home loathe academic colonialism. Any correlation with political attitudes, if any, will follow from choosing a professional ideologythose becoming globalists develop more favourable views towards globalization in order to eliminate cognitive dissonance.

The status model presumes that class will directly influence choosing a more or less rewarding professional niche: The ecological model holds that age, rather than class, may emerge as a principal variable, especially in times of rapid economic change.

Post-Soviet academic history offers a natural-historical experiment that will allow a comparison of these three explanations as to the choice of localism or its opposite.

\section{The setting}

Sociology first emerged in Russia within the international positivist and social survey movements in the second half of the nineteenth century, but during Stalin's rule, between 1930s and the beginning of 1950s, the word was banned and the practice of empirical social research was suppressed. The gradual revival started in the early 1950s, a result of pressure from global cultural trends combined with attempts to increase efficiency within the planned economy (Sokolov 2011). Nevertheless, there were no undergraduate programmes in sociology; 'applied sociology' was only available at graduate level in some universities. Party philosophers continued checking theoretical developments, insisting that sociology was the 
applied 'subdiscipline' of historical materialism -the only true theory of society (Titarenko \& Zdravomyslova, 2017).

Official philosophers also severely restricted intellectual imports from the West; few books were translated into Russian and citing Western theories as a source of inspiration was risky. The end to this state came with Perestroika. Between 1985 and 1992 several important developments occurred. The Party lost its ideological monopoly and the importation of Western sociology or the opening of higher education programmes in sociology were no longer obstructed. Moreover, as departments responsible for teaching historical and dialectical materialism, scientific Communism, and political economy of socialism, subjects present at every higher education institution, obviously lost their relevance in the shifting times, their employees had to rebrand them. A widespread tactic was to rename them as departments of sociology or political science. While the first sociology departments emerged in the Soviet era, the rapid wave of institutionalization of sociological education in 19901992 predominantly emerged from this sort of conversion: thus, in 1989 there were only 2 universities offering undergraduate programmes in sociology; by 1993 their number skyrocketed to 50 . As a result, the number of individuals identifying themselves as sociologists proliferated.

The principal new players appearing were Western foundations, including George Soros's Open Society Institute, the Ford and MacArthur foundations, among dozens of others who supported what was seen by them as building social sciences that met international standards in Russia as a part of transition to liberal democracy. They administered research grants, distributed scholarships, gave money for foreign travel for conferences or internships, and provided institutional support for Western-style private research centres and universities appearing alongside the older public institutions. During the economic crisis of the 1990s, those institutions supported by Western money were much more well-to-do financially than those supported exclusively from the Russian state budget; after the 1998 
devaluation of the rouble, a professor's salary at a major Russian public university equalled some seventy dollars a month, while some of the Western-supported universities were able to pay graduate student scholarships of two hundred dollars a month.

The economic growth of the early 2000s reduced this gap. Moreover, the Russian state, suspicious of alleged interference by Western foundations in Russian politics, gradually forced them out of the country. At the same time, however, the Ministry of Science and Education took over the globalist agenda of the foundations and continued their policies of supporting research demanded by the international academia. Thus, under the global institutional pressures, the Ministry formulated its tasks in terms of increasing the country university's position in international rankings and continued lavishly rewarding the same centres and universities Soros and others had previously supported. That allowed private institutions to continue after the Western sponsorship was reduced or rescinded.

For much of the post-Soviet period, the cleavage between globalists and localists formed one of the central nerves of sociological community life; institutions and networks of scholars were identified by their position on one of the sides of the divide. Indeed, both positions were rarely, if ever, present in their extreme forms. In Russia, presumably as elsewhere, localists (at least those continuing to call themselves "sociologists") are unlikely to deny completely the value of any Western intellectual products. Instead, some of them insist that much of the imported theorizing fits poorly with the needs of understanding Russian society. ${ }^{3}$ Others add that Russia possess a sociological tradition of its own, which, while emerging from the sources imported from the West, developed independently on Russian soil and currently offers an intellectual resource not surpassed by any foreign theorizing. Those who share this belief often accept the role of historians of national sociology. On the practical side, all localists strongly agree that following and contributing to ongoing debates in foreign-language journals should not be regarded as a paramount measure of professional worth for a sociologist in Russia. The tensions increased in 2008- 
2012 when the Ministry launched a series of initiatives aimed at boosting the international visibility of Russian scholarship and incorporated metrics of international recognition (e.g., indexes derived from Web of Science and Scopus citation databases) in the systems of research evaluation inside the country. That was the situation in 2009-2011 when the reported study took place.

\section{The study}

The research presented here is a community study analysing the structure of a local scholarly community as it existed in 2009-2011. It was accompanied by a microhistorical study covering the period from 1984 to 2009. Our aim was to trace career paths and depict intellectual preferences and workstyles of a sample including all those who could be defined as a sociologist active in St Petersburg during this period.

\section{The sample}

The process of forming the sample is described in detail elsewhere (Sokolov 2012). The criteria of defining individuals as sociologists were based on their (a) working at one of city's divisions having 'sociology' in their name (research centres, institutes, university departments); (b) publishing in one of the most important sociological periodicals and giving St Petersburg as their affiliation; (c) participating in a major sociological convention and giving St Petersburg as their location; (d) being members of the local sociological association (St Petersburg Association of Sociologists). These criteria provided a list of 622 individuals, around 350 of whom were active in the period of our study.

The choice of a geographical locality as a setting for studying scholarly communities requires additional explanation. The rate of academic mobility in Russia is very low by international measures, and moving to another city after defending one's $\mathrm{PhD}$ a rare occurrence during the period covered by our study. 
The local sociological population thus fulfilled the criterion classical community studies relied upon: isolated with a reasonable chance of spending one's whole academic life without ever leaving it (40 percent of those surveyed in 2009 reported never going to an academic event outside St Petersburg). It was although sizable enough ${ }^{4}$ and diverse enough to serve as Russian sociology writ small. Sociology BA diplomas were awarded by a dozen public universities. There also existed the Sociological Institute of the Russian Academy of Sciences, Centre for Independent Sociological Research, and the European University at St Petersburg, the latter two private and largely Western-sponsored at the time of the study, and a local branch of the Higher School of Economics - a newly established public university siding with the globalist camp.

\section{Methods}

The study relied on a wide array of methods, but in this paper we deal only with the results of a survey covering 251 subject-approximately 70 percent of the city's sociologists active in 2009 when it was conducted. Interviewers contacted potential informants via e-mail, phone, or personally, met them and either handed them a questionnaire or read questions from it and marked answers if subjects preferred so. When subjects could not be contacted in person, the questionnaire was sent to them via e-mail ( 23 cases). The survey was carried out between June and September, 2009. As far as we could detect, the sample accurately reproduced major demographic parameters of the general population ( $56.1 \%$ female, $43.9 \%$ male in the sample, $54.1 \%$ female and $45.9 \%$ male in the population, average age 47 years in the sample and 49 years in the population). Central figures mentioned in interviews or in answers to survey questions about colleagues with whom an individual collaborated were overrepresented, while peripheral agents were somewhat underrepresented; the sample also probably underrepresented those involved in applied studies, but covers those doing academic research almost without exclusion. 


\section{Variables and measures}

Dependent variables. The survey included questions on a wide variety of aspects of professional life, including an individual's sources of income, their professional fields of view -lists of periodicals read regularly, conferences attended, authors read and books that most influenced one's intellectual careers, methods preferred and used, social networks (namegenerating questions about those offering one a job, inviting to give a talk, etc. were included), attitudes towards various socio-political and professional issues, and a list of social and demographic questions. We complemented their analysis with analysis of publication and citation data

This list of variables allowed for a construction of two measures of localism and globalism, attitudinal or declarative and behavioural:

\begin{tabular}{|l|l|}
\hline Russian sociologists should preserve and develop the national & -.805 \\
sociological tradition & .528 \\
\hline Russian sociology has lagged behind the Western for decades (otstala & \\
\hline Western theories do not explain much in Russian life. We need to work & -.660 \\
with native theoretical models & \\
\hline For a Russian sociologist, it is more important to read English (German, & .617 \\
French) books and journals, than books and journals in Russian & \\
\hline Doing research, sociologists ought to think first of all about the & -.860 \\
interests of their country and their state (gosudarstva) & \\
\hline
\end{tabular}

Table 1. The Globalism-Localism scale scale (with factor loadings) 
(1) Attitudinal Globalism-Localism (G-L) scale. The items included in the scale are listed in Table 1. Each item was evaluated on a four-point Likert scale ('completely disagree', 'mostly disagree", 'mostly agree', 'completely agree'). The weight of each item was determined by principal component analysis with Varimax rotation (analysis extracted one component with eigenvalue exceeding 1, loadings reported in the table). The component explained $51.6 \%$ of variance. We normalized the scale so that it had a mean of 0 and standard deviation of 1 .

(2) Data on the professional field of view-the behavioural measure-In addition to the attitudinal measure, we analysed the professional fields of view of our subjectssets of figures and editions they claimed familiarity with. These sets were chosen from lists that comprised (a) 15 major Russian-language social scientific periodicals and selected English-language periodicals (the task was to identify if an individual reads this periodical 'regularly, several papers a year', 'from time to time, no more than 1-2 papers a year', 'heard of a journal, but never read it', 'never heard of the journal'); (b) names of 20 well-known sociologists, Russian as well as international, frequently mentioned in interviews (the subjects were asked to say if they have read any works by the authors) and (c) answers to the question about 5 books 'influencing most your development as a sociologist' (most frequent answers were coded). The data were then factor-analysed with the analysis producing two factors-one loaded with older Russian-language periodicals such as Sotsiologicheskie issledovanija and older figures of Soviet sociology, such as Vladimir Yadov, Gennadii Ossipov and Zhan Toschenko, and the second one loaded with those, lesser known in Russia at the time, important international figures such as Bruno Latour or Norbert Elias, and also some newer periodicals, less well recognized by state academic institutions, but trying to follow 'international best practices', such as the online Economic Sociology. We called them the Yadov and Latour scales, respectively. We also calculated the 
differences between individuals' scores on both scales (Latour-Yadov, L-Y scale) to measure preferences for one or the other set of editions and figures.

We recognised that these two variables could influence each other (both globalist and localist attitudes could influence behaviour and vice versa-behaviour may require rationalization in terms of professional ideologies), and so they figure both as dependent and independent variables in the following analysis.

Independent variables. As our major aim was to test several suppositions on the sources of globalist or localist attitudes, we wanted to include data on three principal groups of independent variables-class membership, ecological pressures at the early stages of an academic career, and wider ideological orientations.

Class variables included parents' education, knowledge of foreign languages after school (an indicator of family's cultural capital widely used in studies of former state-socialist societies) and parents' occupation.

C1. Parents' education was measured by completed years of formal schooling, with candidate of science (lower level) dissertation defence counting as 3 years (usual period of formal postgraduate studies (aspirantura), and doctor of science (higher-level dissertation) counting as 3 additional years. We calculated the education of both parents (whose educational attainments were correlated at 0.5 level).

C2. Knowledge of foreign languages were estimated by asking to identify if subjects were able to perform different tasks after completing secondary school (read a scholarly article, give a public talk, etc.) in three principal European languages studied in Russian schools (English, German or French). Positive statements were then added to receive an index of language proficiency. 
C3. Parents' occupation. We asked subjects about their parents' occupation at the moment they graduated from secondary school. We later experimented with several ways of coding applying different class schemas. Regretfully, there is no consensus on which schema best fits the Russian situation, and so we decided to use two very simple measures-(C3.1) did individual had at least one parent in an academic job at the age of completing secondary school (including higher education, Academy of Sciences institutions, or applied research institutes) and (C3.2) did individual have at least one parent in a supervisory job at the same moment. Both were binary variables with 1 corresponding to positive answer.

Ecological variables included age and economic niche an individual occupied. Principally, ecological influences are determined by Age (A), measured in years.

In addition, we included direct characterization of sources of academic income, including Teaching (I1)-share of income in the previous 12 months coming from teaching or performing administrative duties at a university ( 1 if share is $50 \%$ or above, 0 if it is below this threshold)

Grants (12)-share of income in the previous 12 months coming from Western grants or scholarships ( 1 if share is $25 \%$ or above, 0 if it is below this threshold). ${ }^{5}$

Finally, as an ideological variable we included a Liberalism-Conservatism (L-C) scale constructed for the aims of this study, which was intended to capture the principal political divide existing in Russia. The scale included items on widely debated political issues such as abolishing capital punishment, suitability of liberal economics and liberal democracy to Russia, approval of Russia's 2008 military intervention in Georgia to protect pro-Russian separatists, approval of same-sex marriage, evaluation of the disintegration of the USSR as a 'great catastrophe' and recognition of the special role of Russian culture. All variables demonstrated high correlations, thus proving the common wisdom that the principal divide in Russian politics is between Western-leaning liberals and conservative Slavophiles is still valid. There was one factor extracted with a principal component analysis with eigenvalue 
exceeding 1 . With religious education excluded, it explained $59.6 \%$ of variation. We normalized the scale so that it also had a mean of 0 and standard deviation of 1 .

We also included Gender (G) coded as a binary variable (0-male, 1-female),

\section{Results}

Figure 2 uses multiple correspondence analysis to visualize relations of the independent variables with each other and with the dependent variables (which are added as supplementary points). ${ }^{6} \mathrm{~A}$ two-dimensional solution explains $46.4 \%$ of observed variance. The first dimension, accounting for approximately $27 \%$ of variance, opposes political liberalism, economic reliance on Western money, absence of teaching, younger age, upbringing in an intelligentsia family, and all sorts of globalist behaviours and attitudes to political conservatism, having a higher education job, older age, and all kinds of isolationist behaviours and attitudes. The scale demonstrates Cronbach Alpha of 0.62 showing a significant degree of consistency. The second dimension, less easily interpretable, possibly deals with academic status attained (it opposes individuals belonging to 1956-1965 generation, male, and reporting having research grants to younger females). As it seems uncorrelated with globalism, it will not be treated here. 


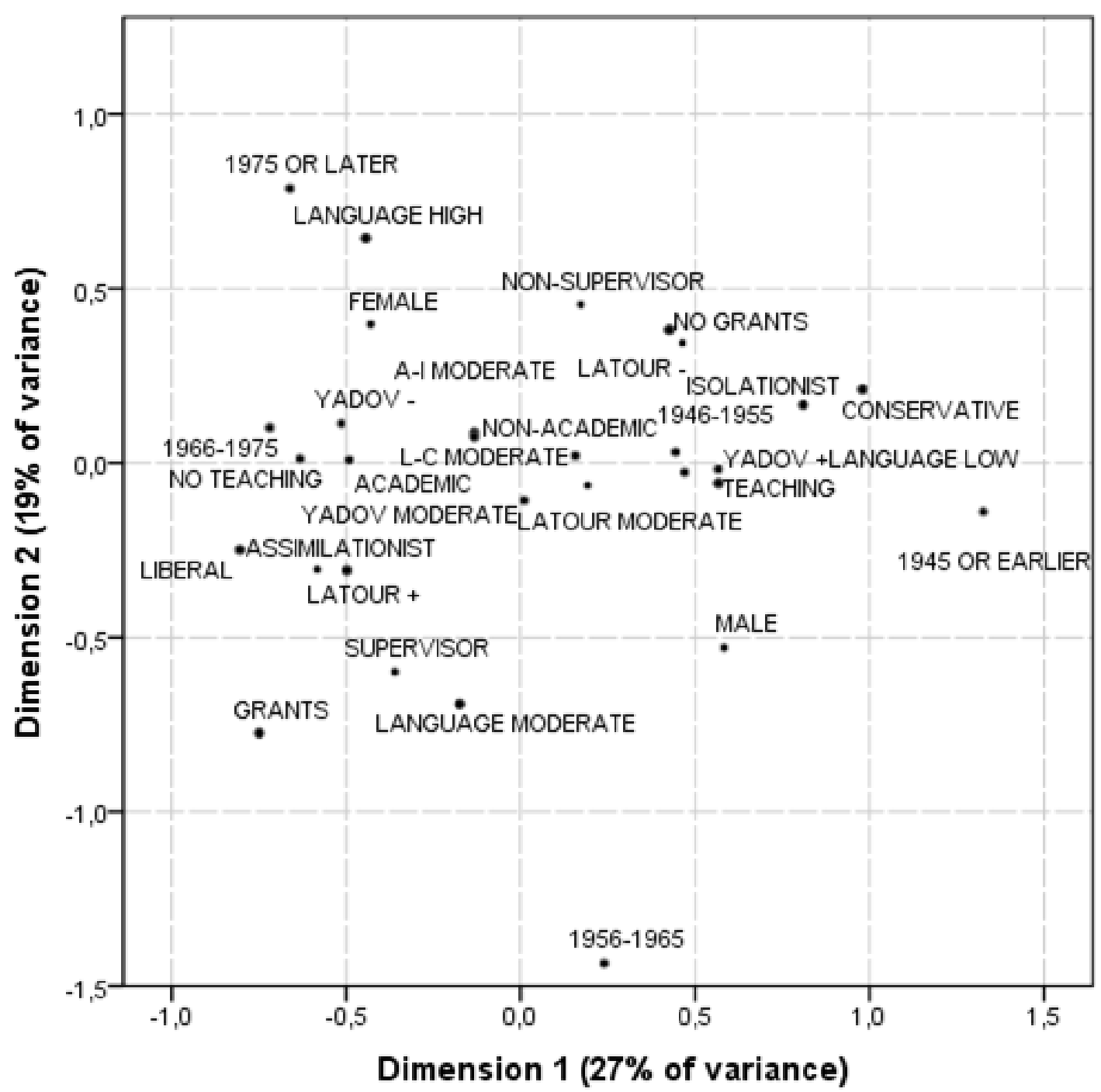

Figure 2. Multiple correspondence analysis of individual attributes (Assimilationism, Yadov and Latour scales - supplementary points)

Tables 2 and 3 represent a series of multiple OLS regression models with, correspondingly, attitudinal G-L scale and behavioural scale of globalism-localism as dependent variables. The first three models in each table correspond to the three groups of variables associated with the theoretical models-the status (Model 1), the ecological (Model2) and the worldview (Model 3). Model 4 enters all groups of variable together. Finally, Model 5 adds the alternative measure of the dependent variable-attitudinal and behavioural-as 
independent variables. We excluded parents' supervisory jobs as it apparently showed no strong association with any other variable.

\begin{tabular}{llllll}
\hline & MODEL 1 & MODEL 2 & MODEL 3 & MODEL 4 & MODEL 5 \\
\hline $\begin{array}{l}\text { Gender } \\
\begin{array}{l}\text { Parents' } \\
\text { education }\end{array}\end{array}$ & 0,001 & $-0,081$ & $-0,123^{* *}$ & $-0,146^{* *}$ & $-0,124^{* *}$ \\
$\begin{array}{l}\text { Parents } \\
\text { academic } \\
\text { Language after }\end{array}$ & $0,200^{*}$ & & & 0,069 & 0,034 \\
$\begin{array}{l}\text { school } \\
\text { Age }\end{array}$ & $-0,045$ & & & 0,018 & 0,028 \\
$\begin{array}{l}\text { Teaching } \\
\text { Western }\end{array}$ & & $-0,234^{* * *}$ & & $-0,047$ & $-0,066$ \\
$\begin{array}{l}\text { grants } \\
\text { L-C Scale }\end{array}$ & & $-0,278^{* * *}$ & & $-0,101$ & $-0,062$ \\
L-Y Scale & & $0,202^{* * *}$ & & $-0,150^{* *}$ & $-0,106^{*}$ \\
\hline $\mathbf{R}^{2}$ corrected & $\mathbf{0 , 0 3 8}$ & $\mathbf{0 , 2 1 7}$ & $\mathbf{0 , 4 6 9}$ & 0,033 & $-0,032$ \\
\end{tabular}

Table 2. OLS regression of Globalism-Localism scale on selected attributes, standardized Betas $\left({ }^{*} \mathrm{p}<0.05, * * \mathrm{p}<0.01, * * * \mathrm{p}<0.001\right)$

On Table 2, Model 1 explains only some $4 \%$ variation in the dependent variable with parents' education being the only significant independent variable. In contrast, Model 2 shows much more definite patterns, with both age and economic niche an individual currently occupies demonstrating direct association with globalist attitudes. Political liberalism, however, performs even better explaining some $47 \%$ of variation alone (Model 3 ). When we enter all three groups of variables into our equation, all class variables become insignificant, but L-C scores and primary economic dependence on teaching remain strongly significant. This suggests that class variables influence choice of professional ideology only indirectly, via social-political attitudes, and the same to a significant degree could be said about ecological variables. ${ }^{7}$ Of variables characterizing economic niche one occupies, only teaching influences G-L scores; the coefficients, however, are at the margins of significance. 
The fact that variables characterizing the economic niche become insignificant after political orientations are included suggests that both the choice of career path and of professional ideology are influenced by the more general ideological overview. Indeed, one can easily suggest why different professional niches are attractive for subjects sharing different values. In the qualitative part of the study not presented here, informants were asked to imagine which profession they would choose if they do not become sociologists. Liberals nearly unanimously voted for various freelance occupations such as journalism or design; conservatives in a surprisingly high numbers mentioned public service. University teachers often defined themselves as a type of civil servants and strongly identify with state causes. This is not surprising when taking into account the character of their work: heavy teaching loads (often exceeding 20 contact hours a week) rarely allow them to pursue their research interests or regard themselves as free-floating intellectuals. As one informant put it, 'those surviving [as university teachers] are people valuing discipline and responsibility above erudite knowledge or originality'. Finally, taking into account the ways most sociological departments in Russia came into being, as described above, one may expect to find more critics of liberalism among university teachers. This has made the choice of a teaching career more attractive to conservatives (who could expect to find similar-minded colleagues), than for liberals. Such self-selection has secured the reproduction of a conservative climate in most departments.

Table 3 shows the models with the same independent variables, but with the Latour-Yadov score as the dependent variable. 'Class' Model 1 again finds the least support, although some of the variables characterizing class position (knowledge of foreign languages after finishing school, parents' education) are approaching statistical significance even in the model with the longest lists of control variables. In contrast to what Table 2 showed, however, ecological variables retain their significance-one's economic basis influences reading practices and 
intellectual influences with Western grants becoming significant. Both political liberalism and globalism turn out to be important in the final model.

\begin{tabular}{|c|c|c|c|c|c|}
\hline & MODEL 1 & MODEL 2 & MODEL 3 & MODEL 4 & MODEL 5 \\
\hline Gender & ,027 &,- 021 & 148 &,- 081 &,- 036 \\
\hline $\begin{array}{l}\text { Parents' } \\
\text { education }\end{array}$ &, $241 * *$ & & & ,128* & 107 \\
\hline $\begin{array}{l}\text { Parents } \\
\text { academic }\end{array}$ &,- 013 & & & -,038 &,- 043 \\
\hline $\begin{array}{l}\text { Language } \\
\text { after school }\end{array}$ & 112 & & & ,072 & ,086 \\
\hline Age & &,$- 266 * * *$ & &,$- 144^{*}$ &,$- 112^{*}$ \\
\hline Teaching & &,$- 238 * * *$ & &,$- 164^{* *}$ &,$- 118^{*}$ \\
\hline $\begin{array}{l}\text { Western } \\
\text { grants }\end{array}$ & &, $352 * * *$ & &, $236 * * *$ &, $226 * * *$ \\
\hline L-C Scale & & &, $673 * * *$ &, $361 * * *$ &, $177^{* * *}$ \\
\hline G-L Scale & & & & &, $308 * * *$ \\
\hline $\begin{array}{l}\text { Rsqr } \\
\text { corrected }\end{array}$ & ,071 & ,321 & 345 & ,430 & ,475 \\
\hline
\end{tabular}

Table 3. OLS regression of Latour-Yadov scale score on selected attributes, standardized Betas $(* p<0.05, * * p<0.01, * * * p<0.001)$

An analysis of an individual's scores at Latour and Yadov scales separately, cited in Table 4, sheds additional light on these findings showing that different factors influence familiarity with local and global intellectual products. Interest to and familiarity with domestic sociology increases with age. At least partially this could be explained by the fact that older sociologists have spent a significant part of their lives in a situation when their contacts with international scholarship were restricted, and they had no choice but to pay more attention to their domestic colleagues. Currently, they may be reproducing reading habits formed in the previous political era. ${ }^{8}$ Globalist attitudes decrease the probability of reading Yadov, probably by providing excuses for not doing so, but do not increase the probability of reading Latour. Immediate causes for reading Latour are different-here funding sources play the greatest role with political liberalism also being of primary importance, even with globalist 
attitudes controlled. Persistence of this effect may signal that our Western funding variable does not capture all aspect of a general choice in favour of an international career path.

\begin{tabular}{|c|c|c|}
\hline & Yadov factor & Latour factor \\
\hline Gender & 040 &,- 011 \\
\hline $\begin{array}{l}\text { Parents' } \\
\text { education }\end{array}$ &,$- 142 *$ & ,009 \\
\hline $\begin{array}{l}\text { Parents } \\
\text { academic }\end{array}$ & ,075 & ,014 \\
\hline $\begin{array}{l}\text { Language } \\
\text { after } \\
\text { school }\end{array}$ &,- 070 & ,051 \\
\hline Age &, $254 * * *$ & ,096 \\
\hline Teaching & 100 &,- 067 \\
\hline $\begin{array}{l}\text { Western } \\
\text { grants }\end{array}$ &,- 015 &, $305 * * *$ \\
\hline L-C Scale & ,052 &, $303 * * *$ \\
\hline G-L Scale &,$- 302 * * *$ & ,133 \\
\hline $\begin{array}{l}\text { Rsqr } \\
\text { corrected }\end{array}$ & ,246 & 340 \\
\hline
\end{tabular}

Table 4. OLS regression of Latour and Yadov scale score on selected attributes, standardized Betas $\left({ }^{*} p<0.05, * * p<0.01, * * * p<0.001\right)$

The narrative putting together these observations is as follows. It seems that general political and cultural liberalism and its opposite, conservatism, are the pivotal elements of our story. They influence choice in favour of domestic or international scholarship in at least two different ways. First, they influence the attractiveness of certain economic niches and the attached lifestyles. Thus, pro-Western liberals were the first to use the opportunity structures of international grant economics when they appeared, both because they found this source of funding more venerable and because they regarded the style of life entailed in grant economics more attractive. This, in turn, favoured familiarizing oneself with figures within the international sociological canon and following Anglo-American literature, as this kind of cultural capital was essential for successfully competing for international grants, scholarships, or positions in the European labour market. In opposition to this, conservatives 
were more likely to take on a teaching job at a mainstream post-Soviet public university that they found more attractive (or at least less repelling). Second, liberalism entailed developing a set of beliefs about the superiority of Western scholarship over the domestic. Globalist attitudes allowed for a disregard of work by older Soviet and Russian scholars-those who believed this scholarship was of inferior quality felt free to ignore it. Interestingly, we have not found the opposite effect: at least according to their own reports, localists were not less aware of international literature.

\section{Discussion and conclusions}

Read in the light of our hypotheses above, these conclusions might be regarded as a strong argument in favour of the worldview model. A set of general political and cultural attitudes directly influences the professional ideology and the occupational niche one picks up. The appeal of intellectual localism is primarily felt by those who favour mighty Russia following its own civilizational path and is not afraid of challenging Western superpowers (as evident from the answers to the questions comprising our Liberalism-Conservatism scale). A question one cannot but ask here is where liberalism and conservatism come from. The link of localism or globalism with social-structural position seems only indirect. There is no correlation with class, economically understood (although the measure we used is admittedly extremely crude) and most links with measures characterizing belonging to status groups of intelligentsia are significant, but at best moderately strong. This fits well with other studies showing that political cleavages in Russia have only moderate correlations with socio-structural variables (Kalinin 2011). This lack of correlation is probably one of the greatest mysteries of Russian society for which currently we do not have a key.

Returning to our hypotheses, there is little evidence that those inheriting more resources are, by the very nature of their privileged class position, likely to occupy the most attractive of the occupational niches. Ecological factors are significant, but their effects are heavily 
mediated by ideological variables. In other words, counter to the wide currency status and ecological model theorizing enjoyed in recent years, an older, Gouldnerian, version of sociology of social-scientific knowledge seem more relevant for the Russian case. At the same time, counter to Gouldner's assumptions, it seems that it is not the resonance with class experience, which is essential in theory adoption. Rather, it is affinity with political and cultural orientations of broad ideological camps that is important-a set of attitudes or beliefs about moral character of certain historical agents and institutions, particularly the Russian state on the one hand and the abstract 'West' on the other. These ideologies draw boundaries between different milieus.

Our survey was conducted back in 2009 , and a reader can ask if much has changed since then. As the survey has not been reproduced, we can rely here only on casual impressions that the localism-globalism divide has become less salient, or at least clashes along this line became less bitter. Globalism has won much of the terrain due to generational changes, bringing younger globalists to the top of profession, and due to the energetic support by the Ministry which dreamt of boosting the country's share of international publications.

As our study dealt with a single country, Russia, its results cannot be generalized to social origins of localism and globalism elsewhere. Indeed, the character of milieus serving as a social basis of each professional ideology might be highly specific for each country. Nevertheless, the present study points to the direction in which such social bases should be looked for.

\section{Acknowledgements}

I am foremost grateful to people with whom we conducted the study reported in this paper-Timur Bocharov, Ekaterina Borozdina, Katerina Guba, Darya Dimke, Ekaterina Moiseeva, Maria Safonova, Lev Shilov, and Kirill Titaev. At different stages of its development, the paper benefited from comments by Vladimir Gelman, Christian Fleck, Oleg 
Kharkhordin, Alexander Libman, Fyodor Pogorelov, Alexandra Makeeva, Irina Olimpieva, Adil Rodionov, Anastasia Tsivinskaya, Vladimir Volokhonsky and three anonymous reviewers. Kirsty Kay's assistance with proofreading the text were invaluable.

\section{Funding}

The study received funding from a governmental block grant allocated to National Research University Higher School of Economics in 2009. 


\title{
NOTES
}

\begin{abstract}
${ }^{1}$ A widely debated issue is if one could decide to be atheoretical and avoid such choice whatsoever without becoming 'eclectic' - which might be described as a choice in itself, and rather poor one.

${ }^{3}$ To give only on example of such an invective, as this article was being finalized, Simon Kordonskii, one of the best known and believed by many to be the most ingenious sociologist in Russia, lamented in an interview to the influential Kommersant newspaper: "Our pollsters, sociologists, social philosopher and others are oriented to imported [research] technologies, and our sociology as such ... emerged with Soros's and other Western foundations' financial support and is using corresponding conceptual schemas. Researchers are using here the same concepts they are using in the West where these concepts emerged and were elaborated on. And this is totally misleading" (Kordonsky, 2017).
\end{abstract}

${ }^{4}$ St Petersburg, for two centuries a capital and the second largest city in Russia, is also second in its present significance as an academic centre (after Moscow). Various statistics, such as numbers of dissertation defenses, numbers of scholars from St Petersburg visiting nation-wide conventions, or numbers of authors of papers in sociological periodicals as documented by the Russian Index of Scientific Citing allows for estimating St Petersburg sociology as around 10 percent of the total amount of sociologists active in Russia

${ }^{5}$ We included questions on various kinds of applied and market research just to find out that there were less than $10 \%$ of those for whom they gave a significant share of income. This made statistical analysis impossible.

${ }^{6}$ For turning interval variables into categorical, we divided their values into 'low' (below 0,5 standard deviation from the average), 'high' (above 0,5 standard deviation) and 'moderate' (everything in between). For age we divided individuals into cohorts.

${ }^{8}$ We are grateful to one of the reviewers for suggesting this mechanism

\section{REFERENCES}

Alatas S. H. (2000). Intellectual imperialism: definition, traits, and problems. Asian Journal

of Social Science, 28(1), 23-45.

Beigel F (2014) Publishing from the periphery: Structural heterogeneity and segmented

circuits. The evaluation of scientific publications for tenure in Argentina's CONICET. Current

Sociology 62(5): 743-765.

Ben-David J and Collins R (1966) Social factors in the origins of a new science: The case of

psychology. American Journal of Sociology 31(4): 451-465. 
Bourdieu P (1975) The specificity of the scientific field and the social conditions of the progress of reason. Social Science Information 14(6): 19-47.

Bourdieu P (1988) Homo Academicus. Cambridge: Polity Press

Collins R (1998) The Sociology of Philosophies. A Global Theory of Intellectual Change.

Cambridge, Mass.: Harvard University Press.

Fahim H and Helmer K (1980) Indigenous anthropology in non-western countries : A further elaboration. Current Anthropology 21(5): 644-663 .

Fourcade M (2006) The construction of a global profession: The transnationalization of economics. American Journal of Sociology 112(1): 145-194.

Frickel S and Gross N (2005) A general theory of scientific/intellectual movements. American Sociological Review 70(2): 204-232.

Gabrenya W K, Kung MC and Chen LY (2006) Understanding the Taiwan indigenous psychology movement: A sociology of science approach. Journal of Cross-Cultural Psychology 37(6): 597-622.

Gareau FH (1988). Another type of third-world dependency: The social sciences. International sociology 3(3): 171-178.

Gouldner A (1970) The Coming Crisis of Western Sociology. London: Heineman Gross, N. (2002). Becoming a pragmatist philosopher: Status, self-concept, and intellectual choice. American Sociological Review, 52-76.

Hanafi S (2011) University systems in the Arab East: Publish globally and perish locally vs publish locally and perish globally. Current Sociology 59(3): 291-309.

Heilbron J (2014) The social sciences as an emerging global field. Current Sociology, 62(5): 685-703. Jahoda G (2016) On the rise and decline of 'indigenous psychology'. Culture \& Psychology 22(2): 169-181. 
Jones B, Reedy, E J and Weinberg B. (2014) 'Age and Scientific Genius' in Simonton, D (ed.) Handbook of Genius. Wiley: 422-450

Kalinin K (2011) Evolutsija sotail'no-professional'nogo razmezhevanija v Rossii (1993-2007

gg): teorija, metodologija, izmerenie [Socio-professional cleavages in Russia (1992-2007). Theory, methodology, measurement] Monitoring obschestvennogo mnenija: Sotsial'nye i ekonomicheskie peremeny [Public opinion monitor: economic and social changes], 101(1): 24-43

Kordonsky S (2017) Sama kontseptsija puti oshibochna" ['The very concept of special path is faulty'] Retrieved from https://www.kommersant.ru/doc/3459946 (May 8, 2018)

Kropp K (2013). Social sciences in the field of power-the case of Danish social science. Social Science Information, 52(3), 425-449.

Lipset SM and Ladd EC (1972) The politics of American sociologists. American Journal of Sociology 78(1): 67-104.

Ramos Z (2014) Local and global communications in Chilean social science: Inequality and relative autonomy. Current Sociology 62(5): 704-722.

Sokolov M (2009) 'Natsional'nye i mezhdunarodnyje reputatsii rossijskih sotsiologov: Naukometricheskij analiz' [National and international reputations of Russian sociologists: A scientometric analysis], Sotsiologicheskije Issledovanija [Sociological research], No.1: 144152

Sokolov M (2011) ‘Rynki truda, karjery I stratifikatcija v sovetskoj sotsiologii’ [Labor markets, careers, and stratification in the Soviet sociology] Ekonomicheskaya Sotsiologija [Economic sociology] 12(4): 37-72

Sokolov M (2012) Izuchaem lokal'nye sotsiologicheskie soobschestva [Studying the local academic communities] Sotsiologicheskie Issledovanija, [Sociological research], No.6: 7692.

Titarenko L \& Zdravomyslova E (2017). Sociology in Russia: A Brief History. Springer. 
Wagner P (2001). A history and theory of the social sciences: Not all that is solid melts into air. Sage.

Zuckerman H (1978) Theory choice and problem choice in science. Sociological Inquiry 48(3-4): 65-95 